\title{
Özofagus Skuamöz Hücreli Karsinomlarında Prognozun Belirlenmesinde D2-40 ve Cox-2 Ekspresyonunun Önemi
}

\section{Importance of D2-40 and Cox-2 Expression in Determination of the Prognosis in Esophageal Squamous Cell Carcinomas}

\author{
Onur Ceylan ${ }^{1 *}$, Nesrin Gürsan², Ayşenur Baş Zeynel ${ }^{3}$, Rabia Demirtaş ${ }^{1}$, Sevilay Özmen ${ }^{1}$, Remzi \\ Arslan $^{1}$ \\ ${ }^{1}$ Atatürk Üniversitesi Tıp Fakültesi Patoloji Anabilim Dalı, Erzurum, Türkiye \\ ${ }^{2}$ İstanbul, Türkiye \\ ${ }^{3}$ Erzurum Bölge Eğitim ve Araştırma Hastanesi Patoloji Anabilim Dalı, Erzurum, Türkiye
}

e-mail: dr.onurceylan@gmail.com,nsgursan@hotmail.com, aysenurbas89@hotmail.com, rabiademirtas@msn.com, ertekozmen@gmail.com, remars1@hotmail.com

ORCID: 0000000170250521

ORCID: 0000000300307347

ORCID: 0000000339661431

ORCID: 0000000187431847

ORCID: 0000000219736101

ORCID: 0000000231984706

*Sorumlu Yazar / Corresponding Author: Sorumlu Yazar: Onur Ceylan ${ }^{1}$

Gönderim Tarihi / Received: 29.09.2019

Kabul Tarihi / Accepted: 29.05.2020

DOI: $10.34087 /$ cbusbed.626354

\section{Öz}

Giriş ve Amaç: Özofagus Skuamöz Hücreli Karsinomu (ÖSHK) dünyada maligniteler içerisinde sekizinci sırada görülmesine rağmen bulunduğumuz coğrafyada beşinci sırada yer almaktadır. Prognozu oldukça kötü olup beş yıllık sağ kalım oranı \%16-20’dir. Surveyinin çok düşük olduğu göz önüne alınacak olursa prognozun belirlenmesi ve tedavinin şekillenmesinde kullanılabilecek yeni belirteçlere ihtiyaç vardır. Bu amaçla son yıllarda önem kazanmış olan COX-2 ve D2-40 belirteçlerinin ÖSHK'lardaki yeri araştırılıp sağ kalım ve prognostik parametrelerle ilişkisi belirlenmeye çalışılmıştır.

Gereç ve Yöntemler: Çalışmamızda ÖSHK'da COX-2 ve D2-40 antikorlarıyla immünhistokimyasal boyama uygulanarak boyanmanın yaygınlığı, yoğunluğu, histoskorları ile prognostik parametreler ve sağ kalım arasındaki ilişki istatistiksel olarak değerlendirildi.

Bulgular: COX-2 ile invazyon derinliği, lenfovasküler invazyon, lenf nodu metastazı, klinik evre ve sağ kalım; D240 ile klinik evre, lenfovasküler invazyon ve lenf nodu metastazı arasında anlamlı ilişki tespit edildi.

Sonuç: Sonuç olarak her iki belirteç de (D2-40 ve COX-2) ÖSHK'da prognozu belirlemede anlamlı bulundu. Anahtar kelimeler: COX-2, D2-40, özofagus skuamöz hücreli karsinom

\footnotetext{
Abstract

Objective: Esophageal squamous cell carcinoma (ESCC) is the eighth most common cancer type in worldwide whereas it has the fifth rank in our region. Prognosis is poor, and survival rate lies between 16-20\% after five years. Considering the low survival, new biomarkers are needed for planning the therapy and the estimation of the prognosis. Materials and Methods: Potential role of COX-2 and D2-40 is investigated in ESCC and their associations with survival and prognostic parameters are sought.

Results: COX-2 staining was found to be associated with invasion depth, lymphovascular invasion, lymph node metastasis, tumor stage and survival whereas D2-40 was found to be associated with lymphovascular invasion, lymph node metastasis and tumor stage.
} 
Conclusion: As a conclusion (COX-2, D2-40), both markers were found useful in the estimation of prognosis of ESCC.

Keywords: COX-2, D2-40, esophageal squamous cell carcinoma

\begin{abstract}
1. Giriş
Özofagus kanseri, maligniteler içinde dünyada sekizinci sırada yer alırken maligniteye bağlı ölümler içinde 6 . sırada yer almaktadır [1]. Türkiye'de ise tüm kanserlerin \%2'sini oluşturmaktadır ve en sık Doğu Anadolu Bölgesinde görülmektedir. Erzurum ili kanser verilerinde özofagus kanseri 5.44/100000 insidansla 5. siradadır. Bu verilerde kadinlarda 6.53/100000 insidansla 3. sirada, erkeklerde 4.43/100000 insidansla 6. sirada görülmekte olduğu bildirilmiştir [2].
\end{abstract}

D2-40 (Podoplanin) ve COX-2 (Siklooksijenaz) ekspresyonlarının kanserlerde tanı ve prognozdaki rolü araştırılmaktadır. D2-40 sadece lenfatik damarlarda bulunan müsin tipi transmembran glikoproteinidir [3] Tümörlerin lenfatik damar invazyonunu belirlemede yardımcı olan bir antikor olmasının yanı sıra tümör hücrelerinde ve tümör stromasında immün reaktivite gösterir [4]. Tümörlerde D2-40 ekspresyonun lenf nodu metastazı, invazyon derinliği, lenfovasküler invazyon, TNM evresi, sağ kalım oranı ile ilişkisi belirtilmiştir [46].

Prostoglandinlerin [PG] hücre proliferasyonu, immün yanıt, anjiogenezis ve apopitoz üzerindeki etkileri bilinmektedir. PG siklooksijenaz yolu ile sentezlenir ve sentezinde siklooksijenaz enzimi rol oynar. Bu enzimin bilinen iki izoformu vardır. COX-1; normal fizyolojik etkiden sorumlu ve hemen hemen tüm dokularda bulunur, COX-2 ise travma, inflamatuar sitokinler, büyüme faktörleri ve onkogenler tarafindan indüklenebilir ve bu yüzden son dönemde kanser araştırmalarında çok fazla yer almaktadır. COX-2 artışı kanserli dokularda azalmış apopitoz, immünsüpresyon, artmış tümör hücre proliferasyonu, anjiyogenez ve metastaz potansiyelinden sorumludur $[7,8]$. ÖSHK'nın erken aşaması olan hücre proliferasyonunda ve tümöral hücrelerinin oluşumunun düzenlenmesinde önemli role sahip olduğu düşünülmektedir. Ayrıca karsinogenez, tümör proliferasyonu ve progresyonu ile ilişkili olduğu bildirilmiştir [9-11]. ÖSHK'nın yüksek insidansa sahip olduğu ve ölüm oranının yüksek olduğu göz önüne alınacak olursa bu kanserin nasıl ilerlediğini anlamak, prognostik parametreleri ve prognostik parametrelerle ilişkili biyobelirteçleri belirlemek önem kazanmaktadır. $\mathrm{Bu}$ nedenle çalışmamızda prognozun ve prognoz ile ilişkili biyobelirteçlerin belirlenmesi amaçlanmıştır.

\section{Materyal ve Metot}

Ocak 2007- Eylül 2014 yılları arasında özofagus karsinomu ön tanısı ile ameliyat edilen ve Atatürk Üniversitesi Tıp Fakültesi Tıbbi Patoloji Anabilim Dalında özofagus karsinomu tanısı konulan materyaller incelenmiştir. ÖSHK tanısı almış, cerrahi öncesi kemoradyoterapi almamış, tümör ve tümöre komşu epitelde displazik değişiklikler izlenen 80 adet olgu çalışmaya dahil edilmiştir. Arşivden olgulara ait parafin bloklar ve camlar çıkartılıp yeniden kesitler alınarak iki farklı patoloji uzmanı tarafından tekrar 1şık mikroskobunda incelenmiştir. Seçilen bloklara immunohistokimyasal olarak COX-2 ve D2-40 antikoru ile boyama yap1lıp, bunların sonuçları önemli prognostik parametreler olan lenf nodu metastazı, invazyon derinliği, lenfovasküler invazyon, TNM evresi, sağ kalım oranı ile karşılaştırılmıştır.

COX-2 ve D2-40 için boyanma yoğunluğu: 0: hiç boyanma olmayan, 1+: zayıf sitoplazmik boyanma gösteren, 2+: orta yoğunlukta sitoplazmik boyanma gösteren, 3+: kuvvetli immün boyanma gösteren şeklinde değerlendirilmiştir [Şekil 1-8]. COX-2 için boyanma yayginlığ $1 \% 0-4=0, \% 5-24=1, \% 25-49=2, \% 50-74=3$ ve $\% 75-100=4$ olarak kabul edilmiştir. D2-40 için boyanma yaygınlığ yüzdelerine göre 0 [\%0]: 1 [\%1-20]: 2 [\%21-40]: 3 [\%41-60]: 4 [\%61-80]: 5 [\%81-100] olarak 6 grupta incelenmiştir. İmmunreaktivite skoru [histoskor] boyanan hücrelerin yoğunluğu ile yaygınlığının çarpımı yöntemi kullanılarak hesaplanmıştır. Histoskor değeri COX- 2 için 0: negatif, 1-4: zayıf, 5-8: orta, 9-12: kuvvetli olarak, D2-40 için 0: negatif, 1-3: zayıf, 4-7: orta, 8-15: kuvvetli olarak değerlendirilmiştir [4-6].

Verilerin normal dağılıma uyup uymadığı D'Agostino Pearson testi ile değerlendirildi. Normal dağılım gösteren ikili veri grupları bağımsız $\mathrm{t}$ testi kullanılarak karşılaştırıldı. Sıralı değişkenlerin karşılaştırılmasında ki kare testi kullanıldı. Sıralı değişkenler arasındaki korelasyon Pearson korelasyonu ile yapıldı. İki uçlu p değerleri $<0.05$ olduğuna test anlamlı kabul edildi. İstatistiksel analizler Medcalc programı (Medcalc ver 16. Ostend, Belçika) ile yapıldı.

\section{Bulgular}

\subsection{Olguların demografik özellikleri ve prognostik} parametre verileri

Vakaların 35'i erkek (\%43,75), 45'i kadın (\%56,25) olup kadın/erkek oranı 1.28 idi. En genç hastamız 33, en yaşlı hastamız 82 yaşında olup vakalarımızda ortalama yaş 55 idi. Olguların invazyon derinlikleri incelendiğinde 9 olgu $(\% 11,25)$ lamina propria, muskularis mukoza veya submukoza invazyonu göstermekteydi (pT1). 20 (\%25) vakada muskularis propria invazyonu izlendi (T2). 50 $(\% 62,5)$ vakada adventisya invazyonu (pT3) izlenirken, bir $(\% 1,25)$ vakada komşu yapılara invazyon tespit edildi (pT4). $27(\% 33,75)$ vakada lenf nodu metastazı pozitif iken 48 (\%60) vakada lenf nodu metastazı negatifti. Lenf nodu metastazı bulunan vakaların 18'inde $(\% 22,5)$ metastatik lenf nodu sayıs1 1-2 (N1), sekizinde (\%10) 36 (N2), birinde $(\% 1,25)$ ise $\geq 7(\mathrm{~N} 3)$ olarak tespit edildi. 5 lenf nodu metastazı varlığ 1 yokluğu belirlenemedi (Nx). 20 (\%25) vakanın histolojik grade'i grade 1, 52 $(\% 65)$ vakanın grade 2 , sekiz vakanın $(\% 10)$ ise grade 3 idi. Vakalarımızın $45^{\prime}$ 'inde $(\% 56,25)$ lenfovasküler invazyon tespit edildi. 80 hastanın 40 tanesi ölü 40 tanesi 
sağ grupta bulunmaktaydı. Ölenlerin yaşam süreleri 1 ile 79 ay arasında değişmekteydi. Ortalama yaşam süresi 21 ay olarak saptand1. 15 vakanın yaşam süresi 12 aydan azd1.
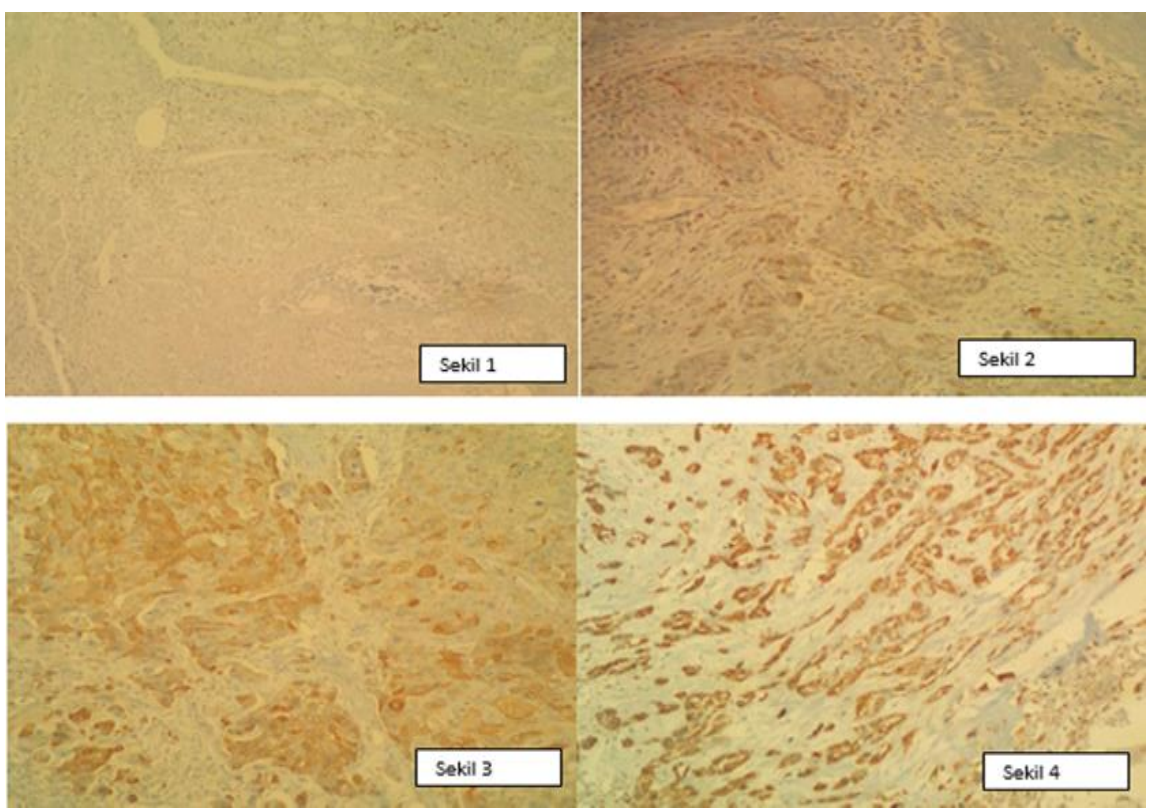

Sekil 1: COX-2 ile negatif boyanma, internal kontrol olarak iltihabi hücrelerde pozitif (x100)

Şekil 2: COX-2 ile (+) sitoplazmik boyanma (x200)

Sekil 3: COX-2 ile (++) sitoplazmik boyanma (x200)

Şekil 4: COX-2 ile (+++) sitoplazmik boyanma (x200)

Klinik bilgilerine ulaşılabilen 55 hastanın 4 tanesinde akciğere metastaz, 2 tanesinde karaciğere metastaz, 1 tanesinde kemiğe metastaz, 4 tanesinde nüks izlenmişti. Vakaların klinik takiplerininin yeterli olmadığını düşündüğümüzden dolayı prognoz karşılaştırması yapılırken hastaların metastaz veya nüks değerlendirilmesinden çok 2 yıllık să̆ kalım ve prognostik parametreler değerlendirildi.

\subsection{COX-2 Ekspresyonunun Değerlendirilmesi}

Histoskorlarına göre değerlendirilme yapıldığında vakaların 74'ünde $(\% 92,5)$ COX-2 ile pozitif boyanma izlenirken 6'sında $(\% 7,5)$ pozitiflik görülmedi. Boyanma yoğunluğu negatif, zayıf, orta, kuvvetli olmak üzere dört grupta incelendi. $14(\% 17,5)$ vakada boyanma yoğunluğu 1 (zayif), 32 (\%40) vakada 2 (orta), 33 vakada $(\% 41,25)$ ise 3 (kuvvetli) olarak saptand. Bir vakada boyanma izlenmedi. Boyanma oranları $6(\% 7,5)$ vakada $0 ; 6$ $(\% 7,5)$ vakada $1 ; 16(\% 20)$ vakada $2 ; 31(\% 38,75)$ vakada 3 ve $21(\% 26,25)$ vakada 4 olarak saptand.
Tümör komşuluğundaki normal epitelde sadece bazal tabakada zayıf bir boyanma görülürken karsinoma insitu ve yüksek dereceli displazi alanlarında epitel tam katı boyunca orta veya kuvvetli yoğunlukta boyanma izlendi. COX-2 boyanma oranı ile invazyon derinliği $(p=0,001)$ ve klinik evre $(p=0,006)$ arasında anlamlı ilişki saptanırken diğer prognostik parametreler ile anlamlı ilişki izlenmedi. Boyanma yaygınlığı ile yoğunluğunun çarpımı sonucu elde edilen histoskor değerleri 0 ile 12 arasında değişmekte olup ortalaması altı idi. İmmunreaktivite skoru (histoskor) 0: negatif, 1-4: zayif, 6-8 orta, 9-12 kuvvetli olarak 4 gruba ayrıld1. Histoskor değerleri incelendiğinde COX-2 histoskoru ile invazyon derinliği $(p=0,017)$, lenfovasküler invazyon $(p=0,006)$, lenf nodu metastazı $(p=0,0203)$, klinik evre $(p=0,018)$, sağ kalım $(p=0,04)$ arasında anlamlı ilişki saptandı. COX-2 boyanma şiddeti ile lenfovasküler invazyon $(\mathrm{p}=0,038)$, lenf nodu metastazı $(\mathrm{p}=0,015)$, klinik evre $(p=0,045)$ ve sağ kalım $(p=0,029)$ arasında anlamlı ilişki saptanırken diğer prognostik parametreler ile anlamlı ilişki izlenmedi (Tablo 1). 

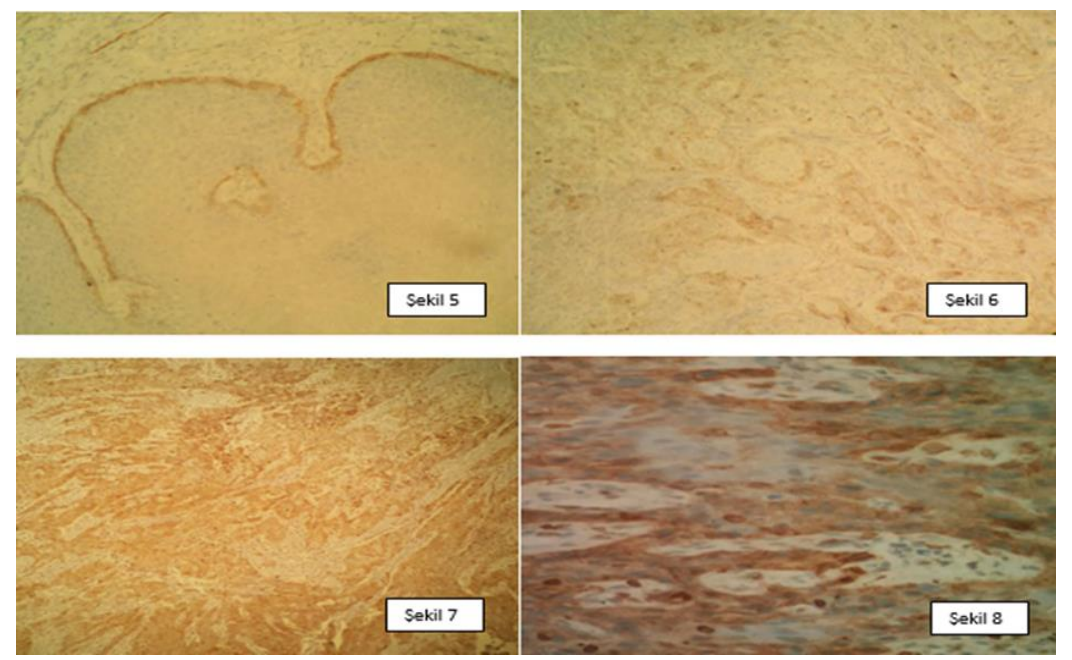

Şekil 5: D2-40 ile tümöre eşlik eden epitel bazalinde pozitif reaksiyon [ $\mathrm{x} 400]$ Şekil 6: D2-40 ile (+) sitoplazmik boyanma (x200)

Sekil 7: D2-40 ile (++) sitoplazmik boyanma (x200)

Şekil 8: D2-40 ile (+++) sitoplazmik boyanma $(\mathrm{x} 400)$

Tablo 1. COX-2 histoskorunun klinikopatolojik parametrelere göre dağılımı

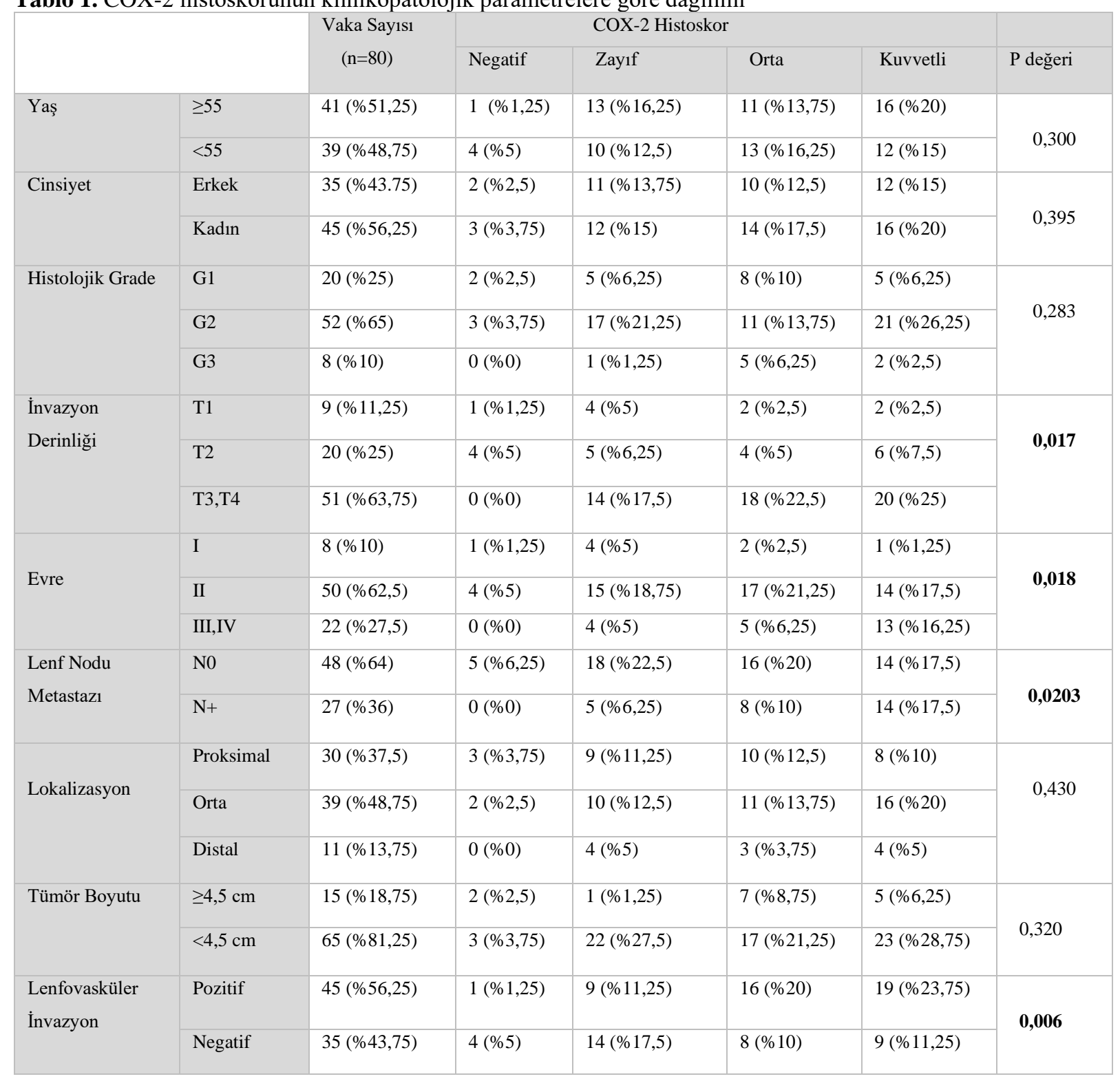




\subsection{D2-40 ekspresyonunun değerlendirilmesi}

Histoskor değerlerine göre değerlendirilme yapıldığında vakaların tümünde D2-40 ile pozitif boyanma izlendi. Boyanma yoğunluğu negatif, zayıf, orta, kuvvetli olmak üzere 4 grupta incelendi. $21(\% 26,25)$ vakada boyanma yoğunluğu: 1 (zayıf), 35 (\%43,75) vakada 2 (orta), 24 vakada (\%30) ise 3 (kuvvetli) olarak saptandı. Boyanma oranları $14(\% 17,5)$ vakada $1 ; 12(\% 15)$ vakada $2 ; 32$ (\%40) vakada $3 ; 16(\% 20)$ vakada 4 ve $6(\% 7,5)$ vakada olarak saptand1. D2-40 ile lenfatiklerde ve tümöral hücre gruplarında sitoplazmik ve membranöz pozitiflik izlenirken tümöre eşlik eden epitel bazalinde pozitif boyanma izlendi.
D2-40 boyanma oranı ile klinik evre (p:0,016), lenfovasküler invazyon (p: 0,046) arasında istatiksel olarak anlamlı sonuçlar elde edildi. D2-40 boyanma şiddeti ile de klinik evre (p: 0,025) arasında istatiksel olarak anlamlı sonuçlar elde edildi. Boyanma yaygınlığ 1 ile yoğunluğunun çarpımı sonucu elde edilen histoskor değerleri 1 ile 15 arasında değişmekte idi. Histoskor değeri incelendiğinde 22 ' sinde zayif, 25 'inde orta, 33 'ünde kuvvetli olarak izlendi. D2-40 histoskor değeri ile ile klinik evre ve lenf nodu metastazı arasında istatiksel olarak anlamlı sonuçlar elde edilirken diğer prognostik parametreler arasında anlamlı ilişki izlenmedi (Tablo 2).

Tablo 2. D2-40 histoskorunun klinikopatolojik parametrelere göre dağılımı

\begin{tabular}{|c|c|c|c|c|c|c|}
\hline & & Vaka Sayısı & & D2-40 Histosk & & \\
\hline & & $(\mathrm{n}=80)$ & Zayif & Orta & Kuvvetli & $P$ değeri \\
\hline Yaş & $\geq 55$ & $41(\% 51,25)$ & $10(\% 12,5)$ & $14(\% 17,5)$ & $17(\% 21,25)$ & \\
\hline & $<55$ & $39(\% 48,75)$ & $12(\% 15)$ & $11(\% 13,75)$ & $16(\% 20)$ & 0,285 \\
\hline Cinsiyet & Erkek & $35(\% 43.75)$ & $7(\% 8,75)$ & $14(\% 17,5)$ & $14(\% 17,5)$ & \\
\hline & Kadın & $45(\% 56,25)$ & $15(\% 18,75)$ & $11(\% 13,75)$ & $19(\% 23,75)$ & 0,275 \\
\hline Histolojik & G1 & $20(\% 25)$ & $8(\% 10)$ & $5(\% 6,25)$ & $7(\% 8,75)$ & \\
\hline Grade & G2 & $52(\% 65)$ & $12(\% 15)$ & $18(\% 22,5)$ & $22(\% 27,5)$ & 0,570 \\
\hline & G3 & $8(\% 10)$ & $2(\% 2,5)$ & $2(\% 2,5)$ & $4(\% 5)$ & \\
\hline İnvazyon & $\mathrm{T} 1$ & $9(\% 11,25)$ & $6(\% 7,5)$ & $3(\% 3,75)$ & $0(\% 0)$ & \\
\hline Derinliği & $\mathrm{T} 2$ & $20(\% 25)$ & $7(\% 8,75)$ & $5(\% 6,25)$ & $8(\% 10)$ & 0,200 \\
\hline & $\mathrm{T} 3, \mathrm{~T} 4$ & $51(\% 63,75)$ & $9(\% 11,25)$ & $17(\% 21,25)$ & $25(\% 31,25)$ & \\
\hline & I & $8(\% 10)$ & $6(\% 7,5)$ & $2(\% 2,5)$ & $0(\% 0)$ & \\
\hline Evre & II & $50(\% 62,5)$ & $14(\% 17,5)$ & $16(\% 20)$ & $20(\% 25)$ & 0,001 \\
\hline & III, IV & $22(\% 27,5)$ & $2(\% 2,5)$ & $7(\% 8,75)$ & $13(\% 16,25)$ & \\
\hline Lenf Nodu & No & $48(\% 64)$ & $17(\% 21,25)$ & $15(\% 18,75)$ & $16(\% 20)$ & \\
\hline Metastazı & $\mathrm{N}+$ & $27(\% 36)$ & $3(\% 3,75)$ & $8(\% 10)$ & $16(\% 20)$ & 0,011 \\
\hline & Proksimal & $30(\% 37,5)$ & $10(\% 12,5)$ & $9(\% 11,25)$ & $11(\% 13,75)$ & \\
\hline Lokalizasyon & Orta & $39(\% 48,75)$ & $11(\% 13,75)$ & $12(\% 15)$ & $16(\% 20)$ & 0,295 \\
\hline & Distal & $11(\% 13,75)$ & $1(\% 1,25)$ & $4(\% 5)$ & $6(\% 7,5)$ & \\
\hline Tümör Boyutu & $\geq 4,5 \mathrm{~cm}$ & $15(\% 18,75)$ & $5(\% 6,25)$ & $4(\% 5)$ & $6(\% 7,5)$ & \\
\hline & $<4,5 \mathrm{~cm}$ & $65(\% 81,25)$ & $17(\% 21,25)$ & $21(\% 26,25)$ & $27(\% 33,75)$ & 0,260 \\
\hline Lenfovasküler & Pozitif & $45(\% 56,25)$ & $10(\% 12,5)$ & $13(\% 16,25)$ & $22(\% 27,5)$ & \\
\hline İnvazyon & Negatif & $35(\% 43,75)$ & $12(\% 15)$ & $12(\% 15)$ & $11(\% 13,75)$ & 0,181 \\
\hline
\end{tabular}

\section{Tartıșma}

ÖSHK erken tanı ve prognozu önceden belirleyecek metotların eksikliği nedeniyle kötü prognoza sahiptir $[1,2]$. Teşhis ve tedavi konusunda son yıllardaki gelişmelere rağmen 5 yıllık sağ kalım \%15- 34 gibi düşük oranlardadır [12,13]. Globokan verilerine göre 2012 yılında Dünya'da toplam 14,1 milyon yeni kanser vakası bildirilmiş olup bunun 456.000'ini özofagus kanseri oluşturmakta idi. Dört yüzbini ise ölümle sonuçlanmıştı [14]. ÖSHK özellikle Asya ülkelerinde diğer ülkelere 
oranla daha sık görülmektedir [15]. Türkiye'de ise tüm kanserlerin \%2'sini oluşturmaktadır. En sık Doğu Anadolu Bölgesinde, özellikle de Ağrı, Erzurum, Artvin, Van, Kars, Gümüşhane, Muş, Hakkâri, Erzincan ve Bitlis'te görülmektedir [2,15,16].

COX-2 prostanoid sentezinin ilk basamağını katalize eden, inflamatuar hadiselerle, karsinogenezisle, artmış anjiogenezisle, apopitoza direnç ile ilişkili bir enzimdir [17]. COX-2 artışı kanserli dokularda defektif apopitozdan, immünosüpresyondan, tümör hücre proliferasyonu, anjiyogenez ve metastaz potansiyeli artışından sorumludur [18]. Çalışmamızda vakaların 74'ünde [\%92,5] COX-2 ile immünreaktivite izlenmiştir. Huang ve arkadaşlarının yapmış oldukları çalışmada COX-2 ile pozitif immünreaktivite oran $\% 74,7$, Zhi ve arkadaşlarının çalışmasında \%77, olarak saptanırken bizimkiyle uyumlu olarak Takatori ve arkadaşlarının çalışmalarında \%90,7 olarak saptanmıştır $[9,19,20]$. Takatori ve arkadaşlarının çalışmalarında COX-2 overekspresyonu ile sağ kalım, invazyon derinliği ve evre arasında anlamlı bir ilişki tespit edilmiştir [20]. Huang, Nazoe, Zhi ve arkadaşlarının çalışmalarında da benzer şekilde tümör progresyonu, tümör hücre proliferasyonu, tümör hücre invazyonu ile COX-2 ekspresyonu arasında anlamlı bağlantı izlenmiştir $[9,19,21]$. Çalışmamızda da literatürle uyumlu olarak COX-2 boyanma oranı ile invazyon derinliği ve klinik evre arasında anlamlı ilişki saptanırken, COX-2 boyanma şiddeti ile lenfovasküler invazyon, lenf nodu metastazı, evre ve sağ kalım arasında anlamlı ilişki tespit edilmiştir.

Vakaların histoskor değerleri incelendiğinde COX-2 histoskoru ile invazyon derinliği, lenfovasküler invazyon, lenf nodu metastazı, klinik evre, sağ kalım arasında anlamlı ilişki saptanmıştır. Önemli prognostik parametreler olan lenfovasküler invazyon, lenf nodu metastazı, invazyon derinliği ve sağ kalım arasında anlamlı ilișki bulunması bu belirtecin ÖSHK vakalarında prognozu belirlemede kullanılabileceğini düșündürmektedir.

COX-2 inhibitörleri kanser tedavisinde 3 farklı şekilde etkili olur. Öncelikle kanser oluşumunun ve ilerlemesinin engellenmesi ayrica kemoterapi ve radyoterapi direncinin önlenmesidir. Tümörün büyümesi ve devamlılığını sürdürmesi için gerekli olan anjiogenezisi inhibe ederek ve apopitozisi aktive ederek tümör progresyonunun önlenmesinde ve tümörojenik aktivitenin engellenmesini sağlarlar [22]. COX-2'nin karsinogenezisin erken aşamasındaki hücre çoğalmasının düzenlenmesinde rol aldığı da bilinmektedir. Bundan yola çıkarak NSAII kullanımı kanser gelişim riskini azaltabilir ve kanser büyümesini inhibe edebilir [10]. COX-2 inhibitörü olan Celecoxib ile farelerde kolon poliplerinin azalmasında yararlı sonuçlar elde edilmiştir [23]. Risk grubu olan veya displazi saptanan hastalarda COX-2 inhibitörleri kullanımı kanser gelişim riskini azaltmada etkili olabilir. Bir çok çalışmada yüksek COX2 ekspresyonu ile kemoterapi ve radyoterapi direnci arasında yakın bir ilişki saptanmıştır $[22,23,24]$. COX-2 inhibitörleri, MDR1 genini (çoklu ilaç direnci geni) baskılayarak kemoterapi direncinin önlenmesinde; antiapopitotik proteinleri (bcl-2 ve bcl-xl) inhibe ederek de kemoterapi ve radyoterapi direncinin önlenmesinde etkili olmaktadır $[25,26]$. Xi ve arkadaşları çalışmalarında artmış COX-2 ekspresyonunun kemoradyoterapinin apopitotik etkisini inhibe ettiğini belirtmişlerdir [24]. Kemoterapi ve radyoterapi direncinde adjuvan tedaviye ek olarak kullanılırsa tedavinin etkisini daha artabilir ve kemoterapiye daha iyi bir yanıt alınabilir.

Müsin tipi transmembran glikoproteini olan D2-40 (Podoplanin) lenfatik endotellerde bulunurken kan damarları endotellerinde bulunmaz. Normal dokularda da nonendotelial hücrelerde de bulunmaktadır. Bu hücrelerin başında yassı epitelin bazal keratinositleri gelmektedir. Bunun yanısıra birçok malign tümörde de D2-40 overekspresyonu bulunmaktadır. ÖSHK'da ekspresyonunun arttığı ve kötü prognoz ile ilişkili olduğu son çalışmalarda gösterilmiştir [4,5,6,27,28,29].

Lenfatik metastaz ÖSHK'nın kötü prognoza ve dolayısıyla düşük sağ kalım oranına sahip olmasının en önemli nedenlerinden biridir ve ne yazık ki erken metastaz varlığını belirleyecek çok az sayıda yöntem mevcuttur. Son zamanlarda D2-40'ın 3 farklı özelliğini kullanarak çeşitli çalışmalar yapılmıştır. Üzerinde en fazla çalışılan müsin tipi transmembran glikoproteini olan D2-40'1n lenfatik invazyonu daha kolay tanımak için lenfatik damar belirleyicisi olarak kullanılmasıdır $[6,27,30,31]$. Chen ve arkadaşları da çalışmalarında D240 'in en hassas ve en spesifik lenfatik damar belirteci olduğunu belirtmişlerdir [31]. Immura ve arkadaşları çalışmalarında D2-40 ile belirlenen lenfovasküler invazyonun lenf nodu metastazı negatif vakalarda bağımsız prognostik faktör olduğunu söylemişlerdir [32]. D2-40'ın üzerinde çalışılan özelliklerinden ikincisi ise Toll ve arkadaşlarının çalışmalarında da belirttiği gibi D2-40'ın lenfatik yapıları arttırmak suretiyle tümör hücresi yayılımında etkili ve dolayısıyla artmış metastaz riski ve kötü prognoz ile ilişkili olmasıdır [30]. Tong ve arkadaşları çalışmalarında ÖSHK'larda artmıș D2-40 ekspresyonu ile lenfatik metastaz ve dolayısıyla artmış invazyon derinliği, lenf nodu metastazı, ileri evre, düşük sağ kalım arasında anlamlı bir ilişki olduğunu belirtmişlerdir [4]. Ma W. ve arkadaşları çalışmalarında ÖSHK'da yüksek D2-40 ekspresyonu ile artmış lenfatik invazyon, nüks, kötü prognoz, düşük sağ kalım oranı arasında anlamlı bir ilişki olduğunu göstermişlerdir [5]. Prasad ve arkadaşları ise oral yassı epitel hücreli karsinomlarda D2-40 ekspresyonu ile lenf nodu metastazı arasında anlamlı bağlantı bulmuşlardır [33]. Rahoduani ve arkadaşları da yapmış oldukları çalışmada da D2-40 pozitif vakalarda yüksek tümörojenik aktivitenin olduğu aynı zamanda D2-40 ekspresyonu ile kanser ilaçlarına direnç, lenfatik metastaz arasında güçlü bir ilişkinin olduğu göstermişlerdir [29].

D2-40'ın üzerinde en az çalıșılan özelliği ise D2-40'ın tümör öncü hücresi ve tümör öncü hücre işaretleyicisi olma özelliğidir [28,33]. Literatürde D2-40 ekspresyonu; tümöre komşu epitelin yalnızca bazalinde, iyi diferansiye tümörlerde baskın olarak tümör solid adalarının periferinde, diferansiasyon kaybının gözlendiği 
tümörlerde ise tümör hücrelerinde diffüz şekilde görülmüştür. İyi diferansiye tümörlerde D2-40 ekspresyonunun orta ve az diferansiye olanlara göre farklı boyandığı birçok çalışmada gösterilmiştir. Orta ve az diferansiye tümörlerde diffüz ekspresyon görülürken eşlik eden epitelin bazalinde ve iyi diferansiye tümör adalarının periferinde görülmesi D2-40'ın tümör hücre migrasynunda, invazyonunda ve karsinogeneziste rolü olabileceğini düşündürmektedir $[4,28,29,34]$. Atsumi ve arkadaşları da çalışmalarında D2-40'1n tümör öncü hücrelerini tespit etmek için kullanılabilecek bir marker olduğunu belirtmişlerdir [28]. Tang ve arkadaşları tümöre eşlik eden normal epitelin bazalinde D2-40 ekspresyonunun görülmesinin nedenini bazal tabakada kök hücrelerinin bulunması ve genetik değişikliklere maruz kalan öncü tümör hücrelerinin buradan kaynaklanmasına bağlamışlardır [4,28,29]. Normal yassı epitel, kök hücreleri içeren bazal tabakadan gelişen matür hücrelerden oluşur. Tümör adalarının ortalarındaki hücreler de matur skuamöz epitel ile benzer morfolojiye sahiptir. SHK'1 oluşturan kompanentlerin heterojen yapısı normal epitel ile benzerlik göstermektedir aynı zamanda tümör adalarının bazalindeki kanser öncü hücreleri kök hücre benzeri özelliklere sahiptir ve bu antijen benzerliğinden dolayı benzer markerlar ile işaretlenebilirler [28,34]. Tümör hücrelerinde D2-40 ekspresyonu da buna bağlıdır. Bundan dolayı D2-40 tümör öncü hücresi ve tümör öncü hücre belirleyicisi olarak kullanılabilir.

Literatürdekine benzer şekilde çalışmamızda da D2-40 dört farklı şekilde boyanmıştır. Tümöre komşu displazik epitelin bazalinde; iyi diferansiye tümörlerde ise tümörün bazalinde daha yoğun iyi diferansiye alanlarda ise daha zayıf; diferansiasyon kaybının daha belirgin olduğu tümörlerde diffüz şekilde ve lenfatiklerde boyanma izlenmiştir. Lenfatik metastazın yoğun olduğu tümörlerde ise tümör hücrelerinde çok kuvvetli bir şekilde boyanma izlenmiştir. Bu durum proliferasyon hızı yüksek olan tümörlerde öncü kanser hücrelerinin oluşum hızının yüksek olması ile izah edilebilir. $\mathrm{Bu}$ da D2-40'1n tümör öncü hücresi olabileceği veya tümör hücre migrasyonunda ve karsinogeneziste rolü olabileceği fikrini desteklemektedir. Tümör öncü hücrelerinin nükslerden sorumlu olabileceği belirtilmektedir. Az sayıda da olsa literatürde bu konuyla ilgili çalışmalar ve bizim sonuçlarımıza dayanarak nüks gelişmesini önlemek için tedavi rejimine antipodoplanin antikorlarının eklenebileceği ve tedavide daha etkili sonuçlar elde edebileceği fikri ortaya çıkmaktadır. Bu konu üzerinde daha fazla çalışılmalara ihtiyaç vardır. Çalışmamızda D2-40 boyanma oranı ile önemli prognostik parametreler olan klinik evre, lenfovasküler invazyon; boyanma şiddeti ile klinik evre, histoskor ile klinik evre ve lenf nodu metastazı arasında istatiksel olarak anlamlı sonuçlar elde edilmiştir. Lenf nodu metastazı evreleme ve prognoz açısından en önemli belirleyicilerden biridir. Lenfovasküler invazyon da gerek lenf nodu metastazı aracılığıyla gerekse bağımsız bir faktör olarak prognozda son derece önemlidir. Bu sonuçlar D2-40'ın ÖSHK'da prognozu belirlemede kullanılabileceğini düşündürmektedir.

\section{Sonuç}

Sonuç olarak her iki belirteç de (D2-40 ve COX-2) ÖSHK'da prognozu belirlemede anlamlı bulunmuştur. D2-40 lenfanjiogenezi arttırarak, COX-2 ise tümörlü dokularda apopitozu inhibe etmenin yanısira anjiyogenez, tümör hücre proliferasyonu ve immünosüpresyonu arttırarak prognozu kötü yönde etkilemektedir. Anti D2-40 antikorlarının kullanımı lenfanjiogenez ve tümörün erken aşamasında rolü olan tümör öncü hücreleri üzerinde etkili olarak tedavide faydalı olabilir. COX-2 inhibitörleri kullanımı ise gerek kanser oluşumunun ve ilerlemesinin önlenmesi gerekse kemoterapi ve radyoterapi direncinin önlenmesinde etkili olarak tedavide faydalı olabilir.

\section{Referanslar}

1. Zhang, Y, Epidemiology of esophageal cancer. World Journal of Gastroenterology, 2013, 19(34), 5598-5606.

2. Şengül, A.T, Özofagus kanserinin epidemiyolojisi, Journal of Experimental and Clinical Medicine 2012, 203-208.

3. Matsui, K, Breitender-Geleff, S ve ark, Podoplanin, a novel 43-kDa membrane protein, controls the shape of podocytes, Nephrology Dialysis Transplant, 1999, 1, 9-11.

4. Tong, L, Yuan, S, Feng, F, Zhang, H, Role of podoplanin expression in esophageal squamous cell carcinoma: a retrospective study, Diseases of the Esophagus, 2012, 25, 72-80.

5. Ma, W, Wang, K ve ark, Clinicopathology significance of podoplanin immunoreactivity in esophageal squamous cell carcinoma, International Journal of Clinical and Experimental Pathology, 2014, 7(5), 2361-2371.

6. Bai, B, Ma, W ve ark, Detection of D2-40 monoclonal antibodylabeled lymphatic vessel invasion in esophageal squamous cell carcinoma and its clinicopathologic significance, Cancer Biology Medicine, 2013, 10(2), 81-85.

7. Gridley, G, McLaughlin, JK ve ark, İncidence of cancer among patients with rheumatoid arthiritis, Journal of the National Cancer Institute, 1993, 85 (4), 307-311.

8. IARC Handbooks on Cancer Prevention, volüme 1, Non-steroida antiinflamatory drugs, IARC Scientific Publication. Lyon, France, 1997

9. Zhi, H, Wang, L, Zhang, J, Zhou, C, Ding, F, Luo, A, Wu, M, Zhan, Q, Liu, Z, Significance of COX-2 expression in human esophageal squamous cell carcinoma, Carcinogenesis, 2006, 27, 1214-1221.

10. Akutsu, Y, Hanari, N, Yusup, G, Komatsu-Akimoto, A, Ikeda, N, Mori, M, Yoneyama, Y, Endo, S, Miyazawa, Y, Matsubara, H, COX2 Expression Predicts Resistance to Chemoradiotherapy in Esophageal Squamous Cell Carcinoma, Annals of Surgical Oncology, 2011, 18, 2946-2951.

11. Williams, CS, Mann, M, DuBois, RN, The role of cyclooxygenases in inflammation, cancer, and development, Oncogene, 1999, 18, 7908 7916

12. Wang, F, Duan, H, Cai, M, Fu, J, Ma, G, Yang, H, Prognostic Significance of the $\mathrm{pN}$ Classification Supplemented by Vascular Invasion for Esophageal Squamous Cell Carcinoma, Thoracic Cancer, 2015, 6(6), 765-771.

13. Sjoquist, KM, Burmeister, BH, Smithers, BM, Zalcberg, JR, Simes, RJ, Barbour, A, Gebski, V, Survival after neoadjuvant chemotherapy or chemoradiotherapy for resectable oesophageal carcinoma: an updated meta-analysis, Lancet Oncology, 2011, 12(7), 681-92.

14. Oesophageal Cancer Estimated Incidence, Mortality and Prevalence Worldwide in 2012

http://globocan.iarc.fr/Pages/fact_sheets_cancer.aspx

15. Boran, M, Göl, H, Özofagus Kanserinde Epidemiyoloji, Turkiye Klinikleri Dergisi, 2007, 3(29), 1-4.

16. Kutlay, H, Cangır, AK, Ökten, İ, Özofagus kanserlerinde epidemiyoloji ve risk faktörleri, Türkiye Klinikleri Cerrahi Dergisi, 2000, 5,1-3 
17. Liu, R, Xu, KP, Tan, GS, Cyclooxygenase-2 inhibitors in lung cancer treatment: Bench to bed, European Journal of Pharmacology, 2015, $769,127-33$

18. Altorki, N, COX-2: a target for prevention and treatment of esophageal cancer, Journal of Surgical Research, 2004, 117, 114-20.

19. Huang, JX, Xiao, W ve ark, Relationship between COX-2 and cell cycle-regulatory proteins in patients with esophageal squamous cell carcinoma, World Journal Gastroenterology, 2010, 16(47), 59755981.

20. Takatori, H, Natsugoe, $\mathrm{S}$ ve ark, Cyclooxygenase-2 expression is related to prognosis in patients with esophageal squamous cell carcinoma, Europian Journal Surgical Oncology, 2008, 34(4), $397-$ 402 .

21. Nozoe, T, Ezaki, T ve ark, Significance of immunohistochemical expression of cyclooxygenase- 2 in squamous cell carcinoma of the esophagus, The American Journal of Surgery, 2005, 189, 110-115.

22. Masferrer, JL, Leahy, KM ve ark, Antiangiogenic and Antitumor Activities of Cyclooxygenase-2 Inhibitors, Cancer Research, 2000, 60(5), 1306-11.

23. Taketo, MM, Cyclooxygenase-2 Inhibitors in Tumorigenesis (Part II), Journal of the National Cancer Institute, 1998, 90, 1609-20.

24. Xi, H, Baldus, SE ve ark, High cyclooxygenase-2 expression following neoadjuvant radiochemotherapy is associated with minor histopathologic response and poor prognosis in esophageal cancer, Clinical Cancer Research, 2005, 11(23), 8341-7.

25. Cao, Y, Prescott, SM, Many actions of cyclooxygenase-2 in cellular dynamics and in cancer, Journal of Cellular Physiology, 2002, 190(3), 279-86.

26. Sobolewski, C, Cerella, C, Dicato, M, Ghibelli, L, Diederich, M, The Role of Cyclooxygenase-2 in Cell Proliferation and Cell Death in Human Malignancies, Hindawi Publishing Corporation, International Journal of Cell Biology, 2010, 21.

27. Schacht, V, Dadras, SS, Johnson, LA, Up-Regulation of the Lymphatic Marker Podoplanin, a Mucin-Type Transmembrane Glycoprotein, in Human Squamous Cell Carcinomas and Germ Cell Tumors, American Journal of Pathology, 2005, 166(3), 913-921.

28. Atsumi, N, Ishii, G, Kojima, M, Sanada, M, Fujii, S, Ochiai, A, Podoplanin, a novel marker of tumor-initiating cells in human squamous cell carcinoma A431, Biochemical and Biophysical Research Communications, 2008, 373, 36-41

29. Rahadiani, N, Ikeda, J, Makino, T, Tian, T, Qiu, Y, Mamat S, Wang, Y, Doki, Y, Aozasa, K, Morii, E, Tumorigenic Role of Podoplanin in Esophageal Squamous-Cell Carcinoma. Annals of Surgical Oncology, 2010, 17, 1311-1323.

30. Toll, A, Gimeno, J, Ferrandiz C, D2-40 immunohistochemical overexpression in cutaneous squamous cell carcinomas: A marker of metastatic risk, Journal of the American Academy of Dermatology, 2012, 67, 1310-1318.

31. Chen, B, Fang, WK ve ark, The prognostic implications of microvascular density and lymphatic vessel density in esophagea squamous cell carcinoma: Comparative analysis between the traditional whole sections and the tissue microarray, Acta Histochemica, 2014, 116(4), 646-53.

32. Imamura, $Y$, Watanabe, $M$ ve ark, Lymphatic Vessel Invasion Detected by the D2-40 Monoclonal Antibody Is an Independent Prognostic Factor in Node-Negative Esophageal Squamous Cell Carcinoma, Journal of Surgical Oncology, 2012, 105, 277-283.

33. Prasad, B, Kashyap, B, Babu, GS, Kumar, GR, Manyam, R, Expression of Podoplanin in Different Grades of Oral Squamous Cell Carcinoma, Annals of Medical And Health Science Research, 2015 5(4), 299-304.

34. Prince, ME, Sivanandan, R ve ark, Identification of a subpopulation of cells with cancer stem cell properties in head and neck squamous cell carcinoma, Proceedings of the National Academy of Sciences, 2007, 104(3), 973-978.

http://edergi.cbu.edu.tr/ojs/index.php/cbusbed isimli yazarın CBU-SBED başlıklı eseri bu Creative Commons Alıntı-Gayriticari4.0 Uluslararası Lisansı ile lisanslanmıștır. 